\title{
A Dataset on the Status Quo of Health and Health-Related Behaviors of Chinese Youth: A Longitudinal Large-Scale Survey in the Secondary School Students of Shandong Province
}

\author{
Shengfa Zhang ${ }^{1}$, Wei Luo ${ }^{2}$, Xiaosheng Dong ${ }^{3}$, Wenxin Chen $^{3}$, Xiangren $\mathrm{Yi}^{3 *}$, Wei Zhou ${ }^{2 *}$, Yue \\ Zhang $^{2}$, Yuanzhi Zhao ${ }^{2}$ \\ ${ }^{1}$ Law School, Beijing Normal University, Beijing 100815, China \\ ${ }^{2}$ National Population Heath Data Center, Chinese Academy of Medical Sciences, Beijing 100730, China \\ ${ }^{3}$ School of Physical Education, Shandong University, Jinan 250061, China
}

\begin{abstract}
This data article describes data acquired from the Database of Youth Health (DYH) program. The DYH program consisted of a multi-wave survey conducted annually in the academic year 2015/2016, 2016/2017, 2017/2018, and 2020/2021 to investigate the status quo of health and health-related behaviors of Chinese junior and senior high school students. A total of 99,327 students from 186 secondary schools in 17 cities of Shandong province participated in the survey. The dataset is longitudinal and consists of rich parameters in aspects of individual information, social-economic status, social interaction, nutrition and diet, psychological cognition, mental health, school adaptation, quality of life, spare-time physical activity, risk behaviors, and physical fitness evaluation results based on the National Student Physical Fitness and Health 2014. It is the first open shared dataset about Chinese adolescents' health and health-related behaviors. It would be valuable and beneficial for policy makers, educational institutions, and other stakeholders to generate or adjust the existing strategies for improving Chinese adolescents' wellbeing.
\end{abstract}

Key words: Chinese youth; youth health; physical fitness; mental health; health-related behavior

\section{Specifications Table}

\begin{tabular}{|c|c|}
\hline Subject area & youth health and health-related behavior \\
\hline Type of data & table, raw data \\
\hline Data format & $* . x \mid s x$ \\
\hline $\begin{array}{l}\text { Parameters for data col- } \\
\text { lection }\end{array}$ & $\begin{array}{l}\text { The dataset consists of demographic information, social-economic status, social interac- } \\
\text { tion, nutrition and diet, psychological cognition, mental health, school adaptation, quality } \\
\text { of life, physical activity, risk behavior, and physical fitness tests results of Chinese youth. }\end{array}$ \\
\hline Data source location & 17 cities in Shandong province, China \\
\hline \multicolumn{2}{|c|}{ Time period of the dataset $2015 / 2016,2016 / 2017,2017 / 2018$, and $2020 / 2021$ academic year } \\
\hline $\begin{array}{l}\text { Description of data collec- } \\
\text { tion }\end{array}$ & $\begin{array}{l}\text { A multi-wave survey was carried out to investigate the status quo of health and health-relat- } \\
\text { ed behaviors of } 99,327 \text { students from } 186 \text { secondary school, with cross-sectional research } \\
\text { design at each survey wave. We recruited and trained physical education teachers to orga- } \\
\text { nize students to answer questionnaires and perform physical fitness tests. }\end{array}$ \\
\hline Data source location & $\begin{array}{l}\text { Population Health Data Archive (PHDA) in National Population Health Data Center (https:// } \\
\text { www.ncmi.cn) }\end{array}$ \\
\hline
\end{tabular}

Received December 8, 2021; accepted December 20, 2021; published online January 26, 2022.

*Corresponding author E-mail: Xiangren Yi, xrenyi@sdu.edu.cn; Wei Zhou, rkjkpt@126.com. 


\begin{tabular}{|c|c|}
\hline \multirow[t]{4}{*}{ Data accessibility } & Repository name: Database for Youth Health \\
\hline & Direct URL:https://www.ncmi.cn//phda/dataDetails.do?id=CSTR:17970.11. \\
\hline & A0031.202107.209.V1.0 \\
\hline & License: CC BY 4.0, authorization from data owner needed. \\
\hline \multirow[t]{10}{*}{ Related research article } & 1. Yi X, Fu Y, Burns R, et al. Weight status, physical fitness, and quality of life among \\
\hline & Chinese adolescents: A cross-sectional study. Int J Environ Res Public Health 2019; \\
\hline & 16(3):2271. doi: 10.3390/ijerph16132271. \\
\hline & 2. Yi X, Fu Y, Burns RD, et al. Body mass index and physical fitness among Chinese adoles- \\
\hline & $\begin{array}{l}\text { cents from Shandong province: a cross-sectional study. BMC Public Health } 2019 ; 19(1): 81 \text {. } \\
\text { doi: } 10.1186 / s 12889-019-6420-2 \text {. }\end{array}$ \\
\hline & 3. Yi X, Liu Z, Qiao W, et al. Clustering effects of health risk behavior on mental health and \\
\hline & physical activity in Chinese adolescents. Health Quality Life Outcomes 2020; 18(1):211. \\
\hline & doi: $10.1186 / s 12955-020-01468-z$ \\
\hline & 4. Dong XS, Ding LJ, Zhang R, et al. Physical activity, screen-based sedentary behavior \\
\hline & $\begin{array}{l}\text { and physical fitness in Chinese adolescents: A cross-sectional study. Front Pediatr 2021; } 9 \text { : } \\
\text { 722079. doi: } 10.3389 \text { /fped. } 2021.722079 \text {. }\end{array}$ \\
\hline
\end{tabular}

\section{VALUE OF THE DATASET}

The dataset provides information of Chinese youth on physical fitness, social interaction, nutrition and diet, school adaptation, quality of life, psychological cognition, mental health, spare-time physical activity, and risk behavior. It helps to better understand the status quo of health and health-related behaviors of Chinese youth.

This dataset is the first open dataset in China about the status quo of health and health-related behaviors of Chinese youth, and it is helpful to promote the establishment of big data on youth health. Research institutions and interdisciplinary experts could conduct further analyses on the relationship among physical fitness, social interaction, nutrition/ diet, school adaptation, quality of life, psychological cognition, mental health, spare-time physical activity and risk behavior of Chinese youth. The dataset could be beneficial for policy makers and educational institutions to optimize the existing strategies and improve Chinese adolescents' wellbeing.

\section{DATA DESCRIPTION}

The Database of Youth Health (DYH) derives from a dedicate program which investigated the health and health-related behaviors of secondary school students. It was a multi-wave survey conducted annually in the academic year of 2015/2016, 2016/2017, 2017/2018 and 2020/2021. A total of 99,327 students from 186 schools in all 17 cities of Shandong province participated in the survey.

The dataset consists of 11 data files in "xlsx" format, and each file contains a unique stuID, through which all files could be associated internally. Each file had the variables of the year of survey, city, and school grade (junior or senior high school), so it is convenient for grouping comparison. The typical variables and number of students in each data file are presented in Table 1.

Due to the lack of research design, the data of 2015/2016 and 2016/2017 academic years only contains school adaptation, quality of life, mental health and physical fitness. The data files of in each academic year are partially different and presented in Table 2.

In order to facilitate users' understanding of dataset, a coding handbook is attached to the dataset ${ }^{[1]}$, which can be accessed from the Population Health Data Archive (PHDA) of the National Population Health Data Center (https://www.ncmi.cn).

\section{STUDY DESIGN AND METHODS}

\section{Study Setting and Participants}

The multi-wave survey was approved by the institutional ethical review broad, and was conducted in 2015/2016, 2016/2017, 2017/2018 and 2020/2021 academic years in 17 cities of Shandong Province, China, including Jinan, Qingdao, Zibo, Zaozhuang, Dongying, Yantai, Weifang, Jining, Tai'an, Weihai, Rizhao, Binzhou, Dezhou, Liaocheng, Linyi, Heze and Laiwu 
Table 1. Variables, items and respondents of each data files in the dataset of Chinese youth health

\begin{tabular}{|c|c|c|c|}
\hline Data file name & Typical variables in each data file & $\begin{array}{l}\text { items in each } \\
\text { table }(n)\end{array}$ & $\begin{array}{l}\text { respon- } \\
\text { dents }(n)\end{array}$ \\
\hline $\begin{array}{l}\text { Individual's in- } \\
\text { formation }\end{array}$ & $\begin{array}{l}\text { stuID, year, city, grade, gender, date of birth, ethnicity, type of registered residence } \\
\text { (Hukou), type of residence address, etc. }\end{array}$ & 39 & 37,495 \\
\hline $\begin{array}{l}\text { Social-economic } \\
\text { status }\end{array}$ & $\begin{array}{l}\text { stuID, year, city, grade, single-child household or not, the number of sister/brother, } \\
\text { who is living with you, parents' education level and occupation, family economic sta- } \\
\text { tus, self-assessment on family relations, access to computer and internet at home, etc. }\end{array}$ & 32 & 35,437 \\
\hline $\begin{array}{l}\text { Social } \\
\text { interaction }\end{array}$ & $\begin{array}{l}\text { stuID, year, city, grade, whether live on campus, number of intimate friends, the name, } \\
\text { school, grade, type of registered residence of intimate friends, what do you often do } \\
\text { when together, what do you often talk when together, etc. }\end{array}$ & 51 & 23,335 \\
\hline $\begin{array}{l}\text { Nutrition and } \\
\text { diet }\end{array}$ & $\begin{array}{l}\text { stuID, year, city, grade, } 26 \text { questions about the dietary of the last week investigated } \\
\text { according to the frequency of different types of food, having breakfast or not, frequen- } \\
\text { cy and degree of hunger, time and length of sleep, self-examination of health status, } \\
\text { etc. }\end{array}$ & 30 & 37,435 \\
\hline $\begin{array}{l}\text { School adapta- } \\
\text { tion }\end{array}$ & $\begin{array}{l}\text { stuID, year, city, grade, school social behavior measured by the School Social Behavior } \\
\text { Scales (SSBS-2) }{ }^{[3,4]}\end{array}$ & 69 & 56,523 \\
\hline Quality of life & $\begin{array}{l}\text { stuID, year, city, grade, measures on quality of life in the Quality of Life Scale for Chil- } \\
\text { dren and Adolescents (QLSCA })^{[5]}\end{array}$ & 53 & 51,290 \\
\hline Physical activity & $\begin{array}{l}\text { stuID, year, city, grade, frequency of different sports, frequency of vigorous exercise, } \\
\text { exercise intensity during breaks and after lunch, frequency of vigorous exercise at dif- } \\
\text { ferent times, self-assessment on exercise frequency and performance, etc. }\end{array}$ & 36 & 35,834 \\
\hline Risk behavior & $\begin{array}{l}\text { stuID, year, city, grade, risk behaviors measured by the questionnaire based on } 2017 \\
\text { State and Local Youth Risk Behavior Survey }{ }^{[7]}\end{array}$ & 27 & 36,278 \\
\hline $\begin{array}{l}\text { Psychological } \\
\text { cognition }\end{array}$ & $\begin{array}{l}\text { stuID, year, city, grade, psychological cognition measured by self-designed question- } \\
\text { naire on the aspects of self-cognition, peer relationship and campus bullying cognition }\end{array}$ & 21 & 14,703 \\
\hline Mental health & $\begin{array}{l}\text { stuID, year, city, grade, mental health measured by the Symptom Checklist } 90 \text { (SCL-90) } \\
\text { scale for senior high school students }{ }^{[9]}\end{array}$ & 94 & 29,944 \\
\hline $\begin{array}{l}\text { Physical fitness } \\
\text { test }\end{array}$ & $\begin{array}{l}\text { stuID, year, city, grade, weight, height, vital capacity, } 50 \text {-m sprint, standing long jump, } \\
\text { sit and reach, one minute rope skipping, } 1000 \text {-m running for boys and } 800 \text {-m running } \\
\text { for girls, pull-ups for boys, bent-leg sit-ups for girls etc. }\end{array}$ & 21 & 80,191 \\
\hline
\end{tabular}

Table 2. Presence of each data file in different academic years in the dataset on Chinese youth health

\begin{tabular}{lcccc}
\hline \multicolumn{1}{c}{ Data file name } & $2015 / 2016$ & $2016 / 2017$ & $2017 / 2018$ & $2020 / 2021$ \\
\hline Individual information & no & no & yes & yes \\
\hline Social-economic status & no & no & yes & yes \\
\hline Social interaction & no & no & yes & yes \\
Nutrition and diet & no & no & yes & yes \\
School adaptation & yes & yes & yes & yes \\
Quality of life & yes & yes & yes & yes \\
Physical activity & no & no & yes & yes \\
Risk behavior & no & no & no & yes \\
Psychological cognition & no & yes & yes & yes \\
Mental health & yes & yes & & yes \\
\hline Physical fitness & yes & &
\end{tabular}

city. To be noted, Laiwu city has been under the jurisdiction of Jinan city since January 2019. Fifty-three secondary schools from 17 cities in 2015/2016 academic years and 132 secondary schools from 13 cities 
in 2016/2017 academic year were randomly selected for the study. Since 2017, the PPS sampling method was adopted, and 100 schools from 10 administrative districts were randomly selected in terms of the specific geography, population and socio-economic level of the province in 2017/2018 and 2020/2021 academic years, while schools with less than 100 students in each grade or less than 300 students in total were not qualified for this study.

\section{Data collection procedure}

We carried out questionnaire surveys and physical fitness tests at each school separately with standard implementation process. We recruited investigators among physical education teachers in each participating schools. After training, they organized questionnaire surveys and administered all physical fitness tests by standard operating procedures. Data collection was incorporated with the annual physical fitness test through the school physical education time mandated by the Ministry of Education in China. The questionnaire surveys were performed with paper in the first two years and online in the rest waves of survey.

\section{MEASURES}

\section{Questionnaire survey}

There are two types of questionnaires: Health and Development Questionnaire for middle school students and Health and Development Questionnaire for high school students. Both consisted of 9 sections of measures.

\section{Individual information}

Individual information we collected includes gender, date of birth, ethnicity, type of registered residence (Hukou), type of residence address, etc.

\section{Social-economic status}

Social-economic status includes: whether single-child household or not; the number of sister/brother and family members; parents' education levels and occupations; family economic status; self-assessment of family relations; whether have access to computer and internet at home; etc ${ }^{[1]}$.

\section{Social interaction}

The social interaction was investigated through following questions: whether being a boarding student; number of intimate friends, and their name, school, grade, academic performance, whether being a class cadre; whether wants to go to college; smoking or not; type of registered residence (urban/rural); "What do you often do when together"; "What do you often talk when together"; etc.

\section{Nutrition and diet}

Nutrition and diet we investigated include following aspects: the dietary in the last week (the frequency of different types of food; having breakfast or not; frequency and degree of hunger); time and length of sleeping; self-examination of health status; etc.

\section{School adaptation}

School adaptation was measured by the School Social Behavior Scales (SSBS-2), which was originally developed by Merrell in $1993^{[2,3]}$ forscreening and assessing social competence and antisocial behavior of students from grade 1 to 12 . The two scales of the SSBS-2 (Social Competence and Antisocial Behavior) were printed on both side of a record sheet, and each scale consists of 32 items rated on a 5-point Likert-type scale $\mathrm{e}^{[3,4]}$.

6. Quality of life

Chinese version of the Quality of Life Scale for Children and Adolescents (QLSCA ${ }^{[5]}$ was used in this study, which includes 49 items to quantify student's life in 13 dimensions, i.e., relationship with teacher, relationship with parents, student partnership, learning capability and attitude, self-perception, physical sense, negative moods and emotions, attitude to homework, convenience of living environment, social activities, sport capacity, self-satisfaction, and others (not specified). The QLSCA items employed a five-point Likert-type scale to assess either frequency or intensity. The recall period was two weeks. Scores for each dimension were calculated, and higher scores indicated a better quality of life. The Chinese version of the QLSCA has been found to have acceptable reliability and validity ${ }^{[6]}$.

\section{Risk behavior}

Risk behaviors of youth are composed of extensive behaviors during the period of school, such as bullying, smoking, unhealthy diet, insufficient exercise, unintentional injuries and violence, and etc. The risk behavior was measured using the method in the 2017 State and Local Youth Risk Behavior Survey ${ }^{[7]}$, which had been revised, modified, and translated into Chinese ${ }^{[8]}$.

8. Psychological cognition (for middle school students)

The current psychological cognition of a middle school 
student was measured by a self-designed questionnaire, which includes 17 questions from three aspects: self-cognition, peer relationship, and campus bullying cognition.

\section{Mental health (for high school)}

The mental health of a high school student was measured by the Chinese version Symptom Checklist 90 $(\mathrm{SCL}-90)^{[9]}$ and 3 self-designed questions. The SCL-90 was comprised of 90 items, each measured on a point scale of distress from "not at all" (0) to "extremely" (4), which quantifies psychopathology in terms of nine primary symptom constructs: somatization, obsessive-compulsive symptoms, interpersonal sensitivity, depression, anxiety, hostility, terror, paranoia, and psychosis. The reliability and validity of the Chinese version has been tested ${ }^{[10]}$.

\section{Physical activity}

Physical activity (PA) was assessed using the Physical Activity Questionnaire for Adolescents (PAQ-A), a revised version of the Physical Activity Questionnaire for Older Children (PAQ-C) ${ }^{[11,12]}$. Adolescents were asked what they often did in their leisure time in the past 7 days. The intensity of PA was scored on a 5-point scale $(1-5)$, with a higher score indicating a higher intensity. Scores $<2$ are categorized into low PA level, and in range of 2-5 are categorized into high PA level ${ }^{[12]}$.

\section{Physical fitness appraise}

The physical fitness tests for all participants followed the standard operating procedures. The participants firstly filled in a standardized form about social-demographic information, such as city, school, age, sex, birth date, grade, and ethnicity. The National Student Physical Fitness and Health 2014 (NSPFH 2014) was used to evaluate proficiency in the following aspects of physical fitness ${ }^{[13,14]}$.

\section{Body mass index (BMI, $\mathrm{kg} / \mathrm{m}^{2}$ ).}

The weight and height of students were measured with light cloth and barefoot using digital electronic scales (HW-VB900, Lejia, China) at an accuracy of $0.1 \mathrm{~kg}$ and $0.1 \mathrm{~cm}$, respectively. BMI was calculated according to the formula BMI $\left(\mathrm{kg} / \mathrm{m}^{2}\right)=$ Weight $(\mathrm{kg}) /[\operatorname{Height}(\mathrm{m})]^{2}$.

\section{Vital capacity (Unit: $m L$ )}

Vital capacity refers to exhaling gas at a uniform rate after inhaling as much as possible, which reflects supply capcity of body oxygen. Electronic vital capacity testers were used. Each student was tested twice, and the maximum value was recorded.

\section{50-m sprint (Unit: minutes' seconds")}

It was used to assess the students' reaction speed and explosive power. When the subjects heard the "go" command, they began a 50-meter run. Time used to finish the whole course was recorded.

\section{Standing long jump (Unit: $\mathrm{cm}$ )}

Standing long jump was introduced to measure lower-limb explosive strength. Every student was asked to stand at the starting line and jump forward as far as possible. Distance from the starting line to the heel of the closest foot was measured. The test was performed for three times, and the best record was retained.

5. One- minute rope skipping (Unit: jumps/minute)

One minute rope skipping was tested for student's sensitivity and coordination using stopwatch, starting whistle and skipping rope of different lengths. Before the test, the students adjusted the length of the rope to the appropriate length, put their legs together and stood naturally. During the test, the students take off with the front soles of their feet and complete the circular jumping movement by "shaking their feet".

\section{Sit and reach (Unit: $\mathrm{cm}$ )}

It was used to evaluate low back flexibility. Every barefoot subject sat on the instrument and gradually extended his or her knees forward. The test was recorded twice, and the better score was retained. The record was in sitting body flexion tester and takes one decimal place.

\section{1000-m / 800-m running (Unit: minutes' seconds")} This running test was used to evaluate cardiorespiratory endurance. All the girls were subjected to run 800 meters and the boys were subjected to run 1000 meters $^{[12]}$. Time for finishing the whole course was recorded.

\section{Pull-ups (Unit: times)}

Pull-up was used for boys to test strength and endurance of upper body muscles. The subject jumped up and pulled on the railing with both hands. After standing still, subjects pulled up with both arms together. The number of pull-ups finished was recorded.

\section{Bent-leg sit-ups (Unit: times/minute)}

Bent-leg sit-up was used for girls to test abdominal strength and endurance. The subjects lay on a mat 
with knees bent 90 degrees, raised the upper body with elbows touching knees. The number of bent-leg sit-ups finished in one minute was recorded.

\section{Data processing}

After personal privacy is anonymized, data processing was conducted using Python 3.7 by two graduate students under the guidance of adolescent health-related experts and supervisions of two scientific data related staff. All personal and sensitive information in the datasets was de-privatized. Structured data were standardized by uniform measurement. Missing data were uniformly marked with "NULL". Outliers, which refer to abnormal data that was far beyond the feature's overall distribution and practically might be caused by error in data input or mistaken filled by participants, had not been processed. Researchers are recommended to process these data according to their own research purposes when re-using the dataset. We had excluded inconsistencies and/or errors, such as inconsistent information of a student in the same school, student number and survey year.

\section{Data analysis}

Data analysis and mining can be carried out through the big data analysis platform of National Population Health Data Center (https://dataservice.imicams. ac.cn/vpn/index.html). Software such as SPSS, Stata, $R$, Python, have been installed on the platform to facilitate users exploring the datasets.

\section{Limitations}

Although the dataset is comprehensive for health of youth and related behaviors, the major limitation of re-utilizing the dataset lies in the discontinuities. Data files of school adaptation, quality of life, mental health and physical fitness in early study period are absent, and the survey was not carried out in 2018/2019 and $2019 / 2020$ academic years, which results in the failure to form sequence data and thus weakens its scientific value. In addition, some outliers in the data need to be processed by researchers according to their own research purposes.

\section{Acknowledgments}

We give many thanks to the physical education teachers who participated in the study during the process of data collection. Thanks also to all the program participants and all the respondents.

\section{Conflict of interests}

The authors declare no competing interests.

\section{Funding}

This study was funded by the National Natural Science Foundation of China (71273157), and the Independent Innovation Foundation of Shandong University (Database Professional HSSDB1502).

\section{Author contributions}

$Y X R, D X S$ and CWX are designers of the study, and they committed to the data collection. $L W, Z W, Z Y$, $Z Y Z, D X S$ and $Y X R$ involved in data processing. $Y X R$ and $Z W$ are responsible for all aspects of the dataset. ZSF drafted and revised the manuscript. All authors reviewed and provided approve the final version before manuscript submission.

\section{REFERENCES}

1. Shandong University. Database for Youth Health. National Population Heath Data Center PHDA, 2021. https://doi. org/10.12213/11.A0031.202107.209.V1.0.

2. Merrell KW, Cedeno CJ, Johnson ER. The relationship between social behavior and self-concept in school settings. Psychol Schs 1993; 30(4):293-8. doi:10.1002/15206807(199310)30:4<293: :AID-PITS2310300402>3.0.CO;2-L.

3. Crowley SL, Merrell KW. The structure of the school social behavior scales: A confirmatory factor analysis. Assess Effect Intervent 2003; 28(2):41-55. doi: $10.1177 / 073724770302800205$.

4. Alfonso VC, Rentz E, Orlovsky K, et al. Test review: school social behavior scales second edition. J Psychoeducat Assess 2007; 25(1):82-92. doi: 10.1177/0734282906291793

5. Wu HR, Liu PL, Meng H. Norm, reliability and validity of children and adolescents' QOL scale. Chin J School Health 2006; (01):18-21. doi: 10.3969/j.issn.1000-9817.2006.01.017. Chinese.

6. Dong $X$, Ding $M$, Chen $W$, et al. Relationship between smoking, physical activity, screen time, and quality of life among Adolescents. Int J Environ Res Public Health 2020; 17(21):115. doi:10.3390/ijerph17218043.

7. Centers for Disease Control Prevention. 2017 State and Local Youth Risk Behavior Survey. available from https://www.cdc. gov/healthyyouth/data/yrbs/pdf/2017/2017_yrbs_standard_ hs_questionnaire.pdf. Accessed December 3, 2021.

8. Yi X, Liu Z, Qiao W, et al. Clustering effects of health risk behavior on mental health and physical activity in Chinese adolescents. Health Quality Life Outcomes 2020; 18(1) : 211. doi:10.1186/s12955-020-01468-z.

9. Derogatis LR, Cleary PA. Confirmation of the dimensional structure of the scl-90: A study in construct validation. 
J Clin Psychol 1977; 33(4):981-9. doi: 10.1002/10974679(197710)33:4<981::AID-JCLP2270330412>3.0.CO;2-0.

10. Feng ZZ, Zhang DJ. Study on the validity of the Symptom Check-List-90 of Chinese version. J Third Military Med Uni 2001; (4):481-3. doi: CNKI:SUN:DSDX.0.2001-04-055.

11. Kowalski KC, Crocker PRE, Donen RM. The physical activity questionnaire for older children (PAQ-C) and adolescents (PAQ-A) manual. Saskatoon, SK, Canada: College of Kinesiology University of Saskatchewan; 2004. Volume 87, pp. 1-38. Available from: https://www.prismsports.org/UserFiles/file/PAQ_manual_ ScoringandPDF.pdf. Accessed: December 12, 2021.

12. Dong $X$, Ding $L$, Zhang $R$, et al. Physical activity, screen- based sedentary behavior and physical fitness in Chinese adolescents: a cross-sectional study. Front Pediatr 2021; 9: 722079. doi:10.3389/FPED.2021.722079.

13. Yi X, Fu Y, Burns R, et al. Weight status, physical fitness, and health-related quality of life among Chinese adolescents: a cross-sectional study. Int J Environm Res Public Health 2019; 16(13):2271. doi: 10.3390/ijerph16132271.

14. Ministry of Education of People's Republic of China. National Student's Physical Fitness and Health (revised in 2014). Available from: http://www.moe.gov.cn/s78/A17/twys_left/ moe_938/moe_792/s3273/201407/t20140708_171692.html. Accessed November 172021. 


\section{数据论文}

\section{中国青少年健康及健康行为数据集: 一项山东省中学生的大 规模纵向调查}

张胜发 ${ }^{1}$, 罗藏 ${ }^{2}$, 董晓升 ${ }^{3}$, 陈文新 ${ }^{3}$, 伊向仁 ${ }^{3 *}$, 周伟 ${ }^{2 *}$, 张月 $^{2}$, 赵远志 ${ }^{2}$

1 北京师范大学法学院, 北京 100875 , 中国

2 中国医学科学院国家人口健康科学数据中心, 北京 100730 , 中国

${ }^{3}$ 山东大学体育学院, 济南 250100 , 中国

\section{摘要}

本篇数据论文描述了基于中国青少年健康数据库项目所产生的数据集。该项目于 2015/2016、2016/2017、 $2017 / 2018$ 和 2020/2021 学年在山东省的 17 个城市的初中生和高中生进行了多轮健康现状和健康相关行为的调查。 共有 186 所中学的 99,327 名学生参加了调查。数据集包括了被调查学生的个人信息、社会经济状况、营养和饮食、 社会交往、心理认知、心理健康、学校适应性、生命质量、课余体育活动、危险行为以及 2014 国家学生身体素质 及健康测评要求的身体素质测量结果。该数据集是我国第一个关于中国青少年健康和健康相关行为的开放共享数 据，有助于政策制定者及教育机构改进青少年健康相关的决策，对改善中国青少年的健康状况和健康行为具有较 高价值。

关键词：中国青少年；青少年健康；体育锻炼；心理健康；健康行为

基金: 国家自然科学基金（71273157）; 山东大学人文社科项目：山东大学青少年运动与健康智能管理数据 库 (HSSDB1502)。

通讯作者: 伊向仁 xreny@sdu.edu.cn; 周伟 rkjkpt@126.com 